Swarthmore College

Works

Psychology Faculty Works

Psychology

$11-1-2012$

\title{
From Reflecting To Making: Psychology In A World Of Change
}

Kenneth J. Gergen

Swarthmore College, kgergen1@swarthmore.edu

Follow this and additional works at: https://works.swarthmore.edu/fac-psychology

Part of the Psychology Commons

Let us know how access to these works benefits you

\section{Recommended Citation}

Kenneth J. Gergen. (2012). "From Reflecting To Making: Psychology In A World Of Change". Europe's Journal Of Psychology. Volume 8, Issue 4. 511-514. DOI: 10.5964/ejop .v8i4.545

https://works.swarthmore.edu/fac-psychology/911

This work is brought to you for free by Swarthmore College Libraries' Works. It has been accepted for inclusion in Psychology Faculty Works by an authorized administrator of Works. For more information, please contact myworks@swarthmore.edu. 


\title{
Editorial
}

\section{From Reflecting to Making: Psychology in a World of Change}

\author{
Kenneth J. Gergen*a \\ [a] Swarthmore College, Swarthmore, United States of America.
}

Europe's Journal of Psychology, 2012, Vol. 8(4), 511-514, doi:10.5964/ejop.v8i4.545

Received: 2012-11-09. Accepted: 2012-11-09. Published: 2012-11-30.

*Corresponding author at: 500 College Avenue, Swarthmore, PA 19081, email: kgergen1@swarthmore.edu

(i) This is an open access article distributed under the terms of the Creative Commons Attribution License

(c) (i) (http://creativecommons.org/licenses/by/3.0), which permits unrestricted use, distribution, and reproduction in any medium, provided the original work is properly cited.

Numerous scholars now characterize our emerging cultural condition as one of rapid, incessant, and accelerating change. As Zygmunt Bauman (2010) comments, for example,

Everything or almost everything in this world of ours keeps changing: fashions we follow and the objects of our attention (constantly shifting attention, today drawn away from things and events that attracted it yesterday, and to be drawn away tomorrow from things that attracted us today), things we dream of and things we fear, things we desire and things we loath, reasons to be hopeful and reasons to be apprehensive.

(p.1)

As I proposed some years ago (Gergen, 2001), such change can be attributed in important degree to the mushrooming developments in communication technologies - from the telephone and radio early last century, through television in mid-century, and now the internet and multi-purpose cell phone. All these technologies essentially contribute to creating, sustaining, or subverting forms of understanding or belief. In today's world the circulation of meaning - in volume, speed, and number of participants - approaches staggering proportions. In the time required to read this sentence aloud, 80 million email messages will have been launched into the world. In the last year alone it is estimated that 8 trillion text messages were sent via cell phones. Everywhere in motion are meanings being shaped and reshaped on virtually every issue of importance to our lives - government, education, religion, family, work, leisure, the economy, love, appearance, and so on.

This transformation in cultural conditions should give us pause. The traditional aim of psychological research is usually couched in terms of prediction and control. We test hypotheses in an attempt to generate propositions that serve as the best fit to the world, with the ultimate hope of making increasingly better predictions about human behavior. As commonly voiced, we hope these predictions can be used in wide-ranging contexts for the betterment of humankind. In effect, our traditional orientation presumes a world of enduring and predictable entities or processes. Yet, in the contemporary world of transience, it is increasingly difficult to locate enduring patterns of behavior. To be sure, we may conjecture about underlying lawfulness, but with continuous change in patterns of action, how the laws apply to contemporary circumstances must continuously be renegotiated. We must seriously confront the limitations in prediction and control. 
In my view, the most promising road ahead is suggested by a statement often attributed to the business sage Peter Druker, "The best way to predict the future is to create it." Rather than chasing after continuously emerging patterns of behavior, we may turn our attention to creating futures that we believe will benefit the human condition. Before outlining such possibilities, however, it is important to underscore a major shift in orientation this will entail. Psychology has long clung to the presumption of value neutral inquiry - with the aim of illuminating "what is," as opposed to making claims to "what should be." To be sure the assumption of value neutrality has always been controversial in psychology, and critical psychologists have made great strides in analyzing the many ideological biases that inhabit our theories and methods. However, if we do engage in forming societal futures, it is imperative to do so with an acute sense of the values that are being both championed and suppressed, and an appreciation for reflexive deliberation.

Let us consider, then, the more specific array of activities invited by a future making perspective. In terms of research, our tradition has favored a search for universal truths, and thus research abstracted from the daily affairs of society. A concern with future building shifts the emphasis to research focused on issues of pressing social importance. Thus, rather than investing primarily in substantiating theoretical truths ("pure" research), the inspiration for inquiry begins with issues of current concern within the society. To a limited extent, psychologists have engaged in such research. The classic work Pettigrew (1971) on racial integration, and Kelman (1987) on peace building are illustrative, along with Kruglanski and Fishman's (2006) more recent explorations of the roots of terrorism, Bar Tal's work on on Arab/lsraeli relations (Bar Tal \& Teichman, 2005), Walkerdine's (1998) research on girls and mathematics education, and Hammack's (2010) incursions into the politics of identity among Israeli and Palestinian youth. While not directly affecting the future, such research can inform the ongoing debates of the times, and in this sense affect policies and practices. More directly engaged in change, however, is participatory action research (Reason \& Bradbury-Huang, 2001). In this case the psychologist works with groups in society to bring about specific changes. Illustrative here are Fine and Torre's (2006) research assisting women in prison, Lykes' (2001) community building work with rural Guatemalan women, and Russell and Bohan's (1999) anti-gay resistance work.

Turning to theoretical work, the challenge of future shaping also invites us to think in new ways. From the traditional standpoint, theory serves as the handmaiden to research, integrating and synthesizing research findings, and thus providing an abstract edifice from which deductions can be made to subsequent practices. That is, theory is a way of integrating reflections of the way the world is. This is not the place to recount the many flaws inherent in this inductivist vision of theory. However, theory begins to acquire future shaping potentials when we begin to see it as a vehicle for generating cultural meaning. Theory is effectively a means of making sense - of ourselves and the world. It defines and interprets and directs, and in this sense has significant potential for cultural transformation. Darwinian theory, for example, has virtually no predictive value (Toulmin, 1961), but its effects on our conceptions of human beings and our place in nature has been enormous. Similarly, the theories of Freud, Marx, and Skinner were catalytic in their cultural impact, even while their evidential grounds were fragile. For good or ill, they were future forming in their effects. It is in this vein that a number of psychologists have been engaged in developing a socio-cultural centered view of the person as a counter to the traditional conception of self-contained or biologically given mental processes (see, for example, Kirschner \& Martin, 2010). The emphasis shifts, then, from the individual to the relational context. And, with a critical eye toward the individualist ideology supported by the traditional view of the person, these discussions have been a major stimulus to my own work on relational being (Gergen, 2009). 
In the case of professional practices, one might say that practitioners have always been engaged in actively creating the future. Psychologists have originated a rich range of therapeutic practices, along with practices for fostering community mental health, physical well-being, the prevention of mental illness, educational efficacy, and so on. How does the proposal for a future-making psychology add anything of significance to this tradition of innovation? Consider the longstanding search for the single best form of therapeutic treatment, with evidence based practices now employed to winnow out the ineffective treatments and to establish a standardized practice for all. Indeed, many believe that cognitive behavioral therapy now approaches this regnant position. However, the efficacy of any therapeutic practice fully depends on cultural beliefs. If one does not believe in mental illness, or attributes his or her suffering to societal conditions, "talking cures" are irrelevant. Thus, if the complex of cultural beliefs is undergoing continuous change, the search for a "single best" practice is counter-productive. In their winnowing function, evidence based practices are also ill considered. Rather than ruling out any form of therapy, from the standpoint of moving with the global flows of meaning, evidence should be used to help in the continuous process of forming and reforming practice.

Finally, if we shift from an emphasis on reflecting the past to making the future, it is vital that we expand our collaborative efforts - both across disciplines and within the society more generally. With multiplicity in viewpoints, the tendency to freeze and finalize is reduced. Rather, one understands more fully the ambiguities surrounding decisions about human betterment, and is sensitized more fully to temporal contingencies. Most important, it is through collaboration that we take in the multiple ideas, beliefs, and values circulating about the discipline, and which enable us to join more effectively in making a contribution to both science and society.

\section{References}

Bar Tal, D., \& Teichman, Y. (2005). Stereotypes and prejudice in conflict: Representations of Arabs in Israeli Jewish society. Cambridge: Cambridge University Press.

Bauman, Z. (2010). 44 letters from the liquid modern world. Malden, MA: Polity Press.

Fine, M., \& Torre, M. E. (2006). Intimate details, participatory action research in prison. Action Research, 4, $253-269$. doi:10.1177/1476750306066801

Gergen, K. J. (2001). The saturated self: Dilemmas of identity in contemporary life. New York: Basic Books.

Gergen, K. J. (2009). Relational being: Beyond self and community. New York: Oxford University Press.

Hammack, P. L. (2010). Narrative and the politics of identity: The cultural psychology of Israeli and Palestinian youth. New York: Oxford University Press.

Kelman, H. C. (1987). The political psychology of the Israeli-Palestinian conflict: How can we overcome the barriers to a negotiated solution? Political Psychology, 8(3), 347-363. doi:10.2307/3791039

Kirschner, S., \& Martin, J. (Eds.). (2010). The sociocultural turn in psychology: The contextual emergence of mind and self. New York: Colombia University Press.

Kruglanski, A., \& Fishman, S. (2006). The psychology of terrorism: "Syndrome" versus "tool" perspectives. Terrorism and Political Violence, 18, 193-215. doi:10.1080/09546550600570119 
Lykes, M. B. (2001). Creative arts and photography in participatory action research in Guatemala. In P. Reason \& H. Bradbury

(Eds.), Handbook of participatory action research. Thousand Oaks, CA: Sage.

Pettigrew, T. (1971). Racially separate or together. New York: McGraw Hill.

Reason, P., \& Bradbury-Huang, H. (2001). Handbook of action research: Participative inquiry and practice. London: Sage.

Russell, G. M., \& Bohan, J. S. (1999). Hearing voices: The uses of research and the politics of change. Psychology of Women Quarterly, 23, 403-418. doi:10.1111/j.1471-6402.1999.tb00371.x

Toulmin, S. (1961). Foresight and understanding: An enquiry into the aims of science. Bloomington, IN: University of Indiana Press.

Walkerdine, V. (1998). Counting girls out: Girls and mathematics. London: Routledge.

\section{About the Author}

Kenneth J. Gergen is a Senior Research Professor at Swarthmore College, and President of the Taos Institute, a non-profit educational organization. He has served as president of two divisions of the American Psychological Association, and as Associate Editor of both the American Psychologist, and Theory and Psychology. Gergen has been a major contributor to social constructionist theory and practice, and a longstanding commentator on psychology and cultural context. Among his major works are Realities and relationships: Soundings in social construction (Harvard University Press, 1995), The saturated self (Basic Books, 1991), An invitation to social construction (Sage, 1999), and Relational being, beyond self and community (Oxford University Press, 2009). Gergen has received many awards for his work, including honorary degrees in both Europe and the US. 